\title{
Occupational risk and work stress in nurses who care for patients with COVID-19 in Emergency of the National Institute of Neoplastic Diseases, 2020
}

\section{[Riesgo laboral y estrés laboral en enfermeros que atienden pacientes con COVID-19 en Emergencia del Instituto Nacional de Enfermedades Neoplásicas, 2020]}

\author{
Herberth Clerk Romero Esteban (D), Mirian Paola Pacora Camargo*iD, Frida Liz \\ Silva Villajulca (iD. \\ Instituto Nacional de Enfermedades Neoplásicas \\ *miripaolapc@gmail.com
}

Received: 12 February 2022; Accepted: 22 February 2022; Published: 07 March 2022

\section{Resumen}

La actual pandemia de COVID-19 está generando múltiples cambios en la realidad sanitaria del país incluyendo situaciones propias del ejercicio profesional de enfermería y de su entorno. Objetivo: Determinar la relación entre el riesgo laboral y el estrés laboral en enfermeros que atienden pacientes con COVID-19 en Emergencia en el Instituto Nacional de Enfermedades Neoplásicas (INEN). Metodología: El estudio fue de enfoque cuantitativo, correlacional, de corte transversal y de diseño no experimental. La población estuvo conformada por 58 enfermeros que laboran en el Servicio de Emergencia del INEN (Lima-Perú). Se utilizaron dos instrumentos: "Cuestionario para medir el riesgo laboral en enfermeros" y la "Escala de medición del estrés laboral en enfermeros". Resultados: El $46,6 \%$ de los participantes presentó un nivel de riesgo laboral alto, 43,1 \% riesgo medio y el 10,3\% riesgo laboral bajo. El riesgo biológico y riesgo psicosocial mostraron un nivel mayoritariamente alto $(69.0 \%$ y $53.4 \%$ respectivamente) y el riesgo químico (46.6 \%), físico (56.9 \%) y ergonómico (48.3\%) un nivel medio preponderante. Por su parte, el estrés laboral presente en los participantes fue de $46.6 \%$ nivel alto, 32,8 \% nivel medio y el 10,3 \% bajo. En cuanto a la asociación de variables, se obtuvo un $p=0.005$ (correlación directa) entre el riesgo laboral y el estrés laboral y un coeficiente Rho de Spearman de 0.364. Por otro lado, se obtuvieron valores $p=0.029, p=0.200, p=0.007, p=0.102$, para el riesgo biológico, riesgo químico, riesgo físico y riesgo ergonómico respectivamente, lo cual determina la inexistencia de asociación de estas variables con el estrés laboral; por su parte, se presentó un valor de $p=0.007$ del riesgo social (correlación directa) y un coeficiente Rho de Spearman $=0.348$. Conclusión: El riesgo laboral se relacionó significativamente con el estrés laboral de los enfermeros que atienden pacientes con COVID-19 en Emergencia del INEN. Asimismo, en cuanto a las dimensiones del riesgo laboral: el riesgo psicosocial también se relacionó significativamente con el estrés laboral. Por otro lado, el riesgo biológico, el riesgo químico, el riesgo físico y el riesgo ergonómico no se relacionaron con el estrés laboral.

Palabras clave: Riesgo laboral y estrés laboral en enfermeros que atienden pacientes con COVID-19.

\begin{abstract}
The current COVID-19 pandemic is generating multiple changes in the country's health reality, including situations typical of the nursing professional practice and its environment. Objective: To determine the relationship between occupational risk and work stress in nurses who care for patients with COVID-19 in Emergency at the National Institute of Neoplastic Diseases (INEN). Methodology: The study had a quantitative, correlational, cross-sectional and non-experimental
\end{abstract}




\section{GHM \\ Journal of Global Health and Medicine}

Vol. 6, $\mathrm{N}^{\circ} 1,2022$

Copyright @ 2022, CINCADER.

ISSN 2523-9511

DOI: https://doi.org/10.32829/ghmj.v6i1.162

design approach. The population consisted of 58 nurses working in the INEN Emergency Service (Lima-Peru). Two instruments were used: "Questionnaire to measure occupational risk in nurses" and the "Scale for measuring work stress in nurses". Results: $46.6 \%$ of the participants presented a high occupational risk level, $43.1 \%$ medium risk and $10.3 \%$ low occupational risk. The biological risk and psychosocial risk showed a mainly high level $(69.0 \%$ and $53.4 \%$ respectively) and the chemical risk $(46.6 \%)$, physical $(56.9 \%)$ and ergonomic $(48.3 \%)$ a preponderant average level. On the other hand, the work stress present in the participants was $46.6 \%$ high level, $32.8 \%$ medium level and $10.3 \%$ low. Regarding the association of variables, a $p=0.005$ (direct correlation) was obtained between occupational risk and occupational stress and a Spearman Rho coefficient of 0.364 . On the other hand, values $p=0.029, p=0.200, p=0.007, p=0.102$, were obtained for biological risk, chemical risk, physical risk and ergonomic risk respectively, which determines the non-existence of association of these variables with the work stress; On the other hand, a value of $p=0.007$ of the social risk (direct correlation) and a Spearman's Rho coefficient $=0.348$ were presented. Conclusion: The occupational risk was significantly related to the work stress of the nurses who care for patients with COVID-19 in the INEN Emergency Department. Likewise, regarding the dimensions of occupational risk: psychosocial risk was also significantly related to occupational stress. On the other hand, biological risk, chemical risk, physical risk and ergonomic risk were not related to work stress.

Keywords: Occupational risk and occupational stress in nurses caring for patients with COVID19.

\section{Introduction}

Historically, since time immemorial, man has transformed nature according to his needs. In this sense, work has been used as a means of personal fulfillment to achieve not only personal or individual but also collective development, promoting capacities and competencies that allow to successfully face the problems that arise, take advantage of material resources and at the same time face occupational risks dependent on the occupation. In 1984, the annual International Labor Conference of the International Labor Organization (ILO) emphasized that the improvement of working conditions and the working environment constitute a positive contribution to national development and a measure of the success of any social and economic policy; to this end, the following principles, among others, were pointed out: Work should be carried out in a safe and healthy environment, and working conditions should be adequate for the well-being of workers and consistent with the dignity of the person (Instituto Nacional de Seguridad y Salud en el Trabajo, 2012).

Before the pandemic in 2019, the World Bank estimated the participation rate in the total world labor force at $60.7 \%$ of the population over 15 years of age (World Bank,2020). This population to achieve high competitiveness requires resources that today are immersed in a changing environment, due to the rapid development of technology, product of globalization and its impact on the social, economic and political environment, which requires the worker greater degree of autonomy, flexibility, initiative and adaptability to new situations, often generating imbalances in the person, which is considered as work stress. Job stress negatively affects the psychological and physical health of workers, and the efficiency of the entities for which they work (Stavroula, et al., 2004)

The World Health Organization (WHO) notes that occupational hazards such as trauma, noise, carcinogens, airborne particles and ergonomic hazards account for a considerable part of the burden of disease from chronic diseases: $37 \%$ of all cases of back pain; $16 \%$ of hearing loss; $13 \%$ of chronic obstructive pulmonary disease; $11 \%$ of asthma; $8 \%$ of trauma; $9 \%$ of lung cancer; $2 \%$ of leukemia; and $8 \%$ of depression. Also, annually, 12.2 million people, mostly in developing countries, die of noncommunicable diseases during their working years. In most countries, work- 


\section{GHM \\ Journal of Global Health and Medicine}

Vol. 6, $\mathrm{N}^{\circ} 1,2022$

Copyright @ 2022, CINCADER.

ISSN 2523-9511

DOI: https://doi.org/10.32829/ghmj.v6i1.162

related health problems cause losses ranging from 4 to $6 \%$ of GDP. It also reports that research has shown that some workplace initiatives can help reduce sickness absenteeism by $27 \%$ and healthcare costs for companies by $26 \%$ (WHO,2017).

As Iniesta refers, "stress can be defined as a process in which environmental demands compromise or exceed the adaptive capacity of the organism, giving rise to biological and psychological changes that can make the person ill", i.e., the negative consequences of stress only occur when the situation exceeds the person's capacity to control it (Iniesta ,2016).

In Latin America and Peru, the magnitude of occupational diseases is still not well known. That is why we seek to know the occupational risk and stress produced by a new disease that is currently facing the world as is the disease COVID-19 reported in January 2020 and that has a high power of transmissibility. In March 2020, after an assessment, WHO decided to declare COVID-19 a pandemic. Currently, WHO and public health authorities around the world are acting to contain the outbreak of COVID-19; however, the persistence of this disease is generating profound changes especially in health personnel in critical areas, as they are frontline staff, all this could affect the development of their personal, family, work and social activities, in different magnitudes (Iniesta ,2016).

In the Peruvian context, Dionisio demonstrated in his study that the higher the occupational risk, the higher the occupational stress among nurses. An adverse work environment can lead to physical and psychological problems, harmful substance and alcohol consumption, absenteeism and productivity losses. Promoting mental health in the workplace and supporting individuals with psychiatric disorders makes it more likely that absenteeism will be reduced, productivity will increase, and the economic benefits of these effects will be realized (Dionisio, 2017).

Likewise, Marcelo et al. (2015) show that nursing professionals are a vulnerable group in the health sector, where hazards materialize and generate work accidents; therefore, the purpose of the research study is to develop strategies that contribute to the control and management of hazards, providing a safe work environment, with due protection and promotion of the health of all workers. The ILO indicates that stress is a dangerous disease for the economies of industrialized and developing countries, harming productivity by affecting the physical and emotional health of workers. Stress is also considered the epidemic of the 21 st century by many international organizations, including the WHO and the ILO.

For many years, the Health Education Authority has classified nursing as one of the most stressful professions due to the responsibility for people's lives and the proximity to suffering, together with the presence of stressors inherent to the physical environment, work and organization (Zambrano, 2006). In this regard, Serrano et al. demonstrated that the frequency of mental health problems in health professionals in charge of emergencies caused by viral epidemics is especially high, indicating a high prevalence of anxiety (45\%), followed by depression (38\%), acute stress $(31 \%)$, burnout $(29 \%)$ and post-traumatic stress $(19 \%)$. Likewise, there are certain sociodemographic, social and occupational factors that significantly increase the risk of suffering mental health problems (Serrano et al., 2020).

Currently, Emergency Department nurses present greater occupational risk due to direct contact with the COVID 19 virus; this situation causes situations of fear, anguish, uncertainty, increased levels of occupational stress, as well as the risk of getting sick and even dying. The purpose of the study was to analyze and understand these circumstances in the nursing staff and propose the implementation of strategies and improvement plans to mitigate this problem. 
Vol. 6, $\mathrm{N}^{\circ}$ 1, 2022

Copyright (c) 2022, CINCADER.

ISSN 2523-9511

DOI: https://doi.org/10.32829/ghmj.v6i1.162

\section{Materials and methods}

A quantitative, descriptive, correlational, cross-sectional, non-experimental design (Hernandez et al., 2014). The sample consisted of a total of 58 nurses working in the Emergency Department of INEN. Data collection was carried out through the application of two instruments: the first was the "Questionnaire to measure occupational risk in nurses" created by Escobar and Vargas (2017), initially adapted by Dionisio (2017) and adapted again for this study. This instrument was composed of 37 questions with dichotomous answers, distributed in 5 dimensions: Biological, chemical, physical, psychosocial and ergonomic risk. Each item had a rating of 1 (Yes) and 0 (No). The final result reflected levels of occupational risk: High, Medium and Low, according to the results obtained. Likewise, each of the dimensions or types of risk were classified in the same way. The second instrument used to measure the level of occupational stress was the "Scale for measuring stress in nurses", created by Preciado et al. (2016) initially adapted by Dionisio (2017) and adapted for the second time for this study. This instrument consisted of a Likert-type scale of 37 items with 4 multiple choice responses (almost never, sometimes, often, almost always) for each question. Each item had a rating of: Almost never (0), Sometimes (1), Often (2), Almost always (3). In this way, the level of work stress was obtained: High, Medium and Low according to the scores obtained by the participants.

Both instruments were validated in the study conducted by Dionisio (2017) and also the updated version for this study. In terms of reliability, both instruments presented a Cronbach's Alpha coefficient of 0.7 obtained, which in itself assured their reliability. On the other hand, the modified and adapted version for the present study obtained the following reliability coefficients: in the Questionnaire to measure Occupational Risk it obtained a Cronbach's Alpha of 0.796 and in the stress measurement scale it obtained a Cronbach's Alpha of 0.803 .

During the research, ethical aspects were applied, such as the signing of the informed consent. For the analysis of the results, descriptive and inferential statistics were applied. The data were processed with the latest version of SPSS statistical software. Subsequently, the level of correlation between the main variables and their dimensions was determined using Spearman's Rho coefficient. Finally, the results were presented in tables and graphs.

\section{Results}

Table 1. Relationship between occupational risk and occupational stress among nurses caring for patients with COVID-19 in the INEN Emergency Department.

\begin{tabular}{|c|c|c|c|c|}
\hline \multirow{7}{*}{$\begin{array}{l}\text { Spearman's } \\
\text { rho }\end{array}$} & & & Occupational Risks & Labor Stress \\
\hline & \multirow{3}{*}{$\begin{array}{l}\text { Occupational } \\
\text { Risks }\end{array}$} & Correlation Coefficient & 1,000 &, $364^{\star *}$ \\
\hline & & Sig. (2-tailed) & &, 005 \\
\hline & & $\mathrm{N}$ & 58 & 58 \\
\hline & \multirow[t]{3}{*}{ Labor Stress } & Correlation Coefficient &, $364^{* *}$ & 1,000 \\
\hline & & Sig. (2-tailed) & ,005 & \\
\hline & & $\mathrm{N}$ & 58 & 58 \\
\hline
\end{tabular}

**. Correlation is significant at the 0.01 level (2-tailed).

In Table 1, the value of $p=0.005$ determines that there is a direct correlation between occupational risk and occupational stress among nurses attending patients with COVID-19 in the Emergency Department of INEN. Likewise, the Spearman's Rho correlation coefficient obtained (0.364) was low, but significant. 


\section{Journal of Global Health and Medicine}

Vol. 6, $\mathrm{N}^{\circ} 1,2022$

Copyright (c) 2022, CINCADER.

ISSN 2523-9511

DOI: https://doi.org/10.32829/ghmj.v6i1.162

Table 2. Relationship between biological risk and occupational stress among nurses caring for patients with COVID-19 in the INEN Emergency Department.

\begin{tabular}{|c|c|c|c|c|}
\hline & \multirow{4}{*}{ Biohazard } & & Biohazard & Labor Stress \\
\hline \multirow[t]{6}{*}{ Spearman's rho } & & Correlation Coefficient & 1,000 &, $287^{*}$ \\
\hline & & Sig. (2-tailed) & & ,029 \\
\hline & & $\mathrm{N}$ & 58 & 58 \\
\hline & \multirow[t]{3}{*}{ Labor Stress } & Correlation Coefficient &, $287^{*}$ & 1,000 \\
\hline & & Sig. (2-tailed) & ,029 & \\
\hline & & $\mathrm{N}$ & 58 & 58 \\
\hline
\end{tabular}

*. Correlation is significant at the 0.05 level (2-tailed).

Table 2 ( $p=0.029$ ) indicates that there is no direct correlation between biological risk and occupational stress among nurses caring for patients with COVID-19 in the INEN Emergency Department.

Table 3. Relationship between chemical risk and occupational stress among nurses caring for patients with COVID-19 in the INEN Emergency Department.

\begin{tabular}{|c|c|c|c|c|}
\hline \multirow{7}{*}{$\begin{array}{l}\text { Spearman's } \\
\text { rho }\end{array}$} & & & Chemical Hazard & Labor Stress \\
\hline & \multirow{3}{*}{$\begin{array}{l}\text { Chemical } \\
\text { Hazard }\end{array}$} & Correlation Coefficient & 1,000 & ,171 \\
\hline & & Sig. (2-tailed) & & 200 \\
\hline & & $\mathrm{N}$ & 58 & 58 \\
\hline & \multirow{3}{*}{ Labor Stress } & Correlation Coefficient & ,171 & 1,000 \\
\hline & & Sig. (2-tailed) & ,200 & \\
\hline & & $\mathrm{N}$ & 58 & 58 \\
\hline
\end{tabular}

In Table 3, the p-value $=0.200$ determines that there is no direct correlation between chemical risk and work stress among nurses attending patients with COVID-19 in the Emergency Department of INEN.

Table 4. Relationship between physical risk and occupational stress among nurses caring for patients with COVID-19 in the INEN Emergency Department.

\begin{tabular}{lllr|r}
\hline & & Physical Risk & \multicolumn{1}{c}{ Labor Stress } \\
\hline \multirow{2}{*}{$\begin{array}{l}\text { Spearman's } \\
\text { rho }\end{array}$} & Physical Risk & Correlation Coefficient & 1,000 & $\mathbf{1 9 8}$ \\
\cline { 2 - 5 } & & Sig. (2-tailed) &. & $\mathbf{1 3 5}$ \\
\cline { 2 - 5 } & $\mathrm{N}$ & $\mathbf{5 8}$ & $\mathbf{1 9 8}$ \\
\cline { 2 - 5 } & Labor Stress & Correlation Coefficient & $\mathbf{1 3 5}$ & $\mathbf{1 , 0 0 0}$ \\
\cline { 2 - 5 } & & Sig. (2-tailed) & 58 &. \\
\cline { 2 - 5 } & $\mathrm{N}$ & & $\mathbf{5 8}$ \\
\hline
\end{tabular}

Table $4(p=0.135)$ shows that there is no direct correlation between physical risk and occupational stress among nurses caring for patients with COVID-19 in the INEN Emergency Department. 
Vol. 6, $\mathrm{N}^{\circ}$ 1, 2022

DOI: https://doi.org/10.32829/ghmj.v6i1.162

Table 5. Relationship between psychosocial risk and occupational stress among nurses caring for patients with COVID-19 in the INEN Emergency Department.

\begin{tabular}{|c|c|c|c|c|}
\hline & & & $\begin{array}{c}\text { Psychosocial } \\
\text { Risk } \\
\end{array}$ & Labor Stress \\
\hline \multirow{6}{*}{$\begin{array}{l}\text { Spearman's } \\
\text { rho }\end{array}$} & \multirow[t]{3}{*}{ Psychosocial Risk } & Correlation Coefficient & 1,000 &, $348^{* *}$ \\
\hline & & Sig. (2-tailed) & & ,007 \\
\hline & & $\mathrm{N}$ & 58 & 58 \\
\hline & \multirow[t]{3}{*}{ Labor Stress } & Correlation Coefficient & ,348 & 1,000 \\
\hline & & Sig. (2-tailed) & ,007 & \\
\hline & & $\mathrm{N}$ & 58 & 58 \\
\hline
\end{tabular}

**. Correlation is significant at the 0.01 level (2-tailed).

In Table 5, the value of $p=0.007$ indicates that there is a direct correlation between psychosocial risk and occupational stress among nurses who care for patients with COVID-19 in the INEN Emergency Department. Likewise, the Spearman's Rho correlation coefficient obtained (0.348) was low, but significant.

Table 6. Relationship between ergonomic risk and occupational stress among nurses caring for patients with COVID-19 in the Emergency Department of INEN.

\begin{tabular}{lllr|r}
\hline & & Ergonomic Risk & Labor Stress \\
\hline \multirow{2}{*}{$\begin{array}{l}\text { Spearman's } \\
\text { rho }\end{array}$} & Ergonomic Risk & Correlation Coefficient & 1,000 & $\mathbf{2 1 7}$ \\
\cline { 3 - 5 } & & Sig. (2-tailed) & .12 & $\mathbf{1 0 2}$ \\
\cline { 2 - 5 } & $\mathrm{N}$ & $\mathbf{2 1 7}$ & $\mathbf{5 8}$ \\
\cline { 2 - 5 } & Labor Stress & Correlation Coefficient & $\mathbf{1 0 2}$ & 1,000 \\
\cline { 3 - 5 } & & Sig. (2-tailed) & 58 & 58 \\
\cline { 2 - 5 } & $\mathrm{N}$ & &
\end{tabular}

Table $6(p=0.102)$ shows that there is no direct correlation between ergonomic risk and occupational stress among nurses attending patients with COVID-19 in the INEN Emergency Department. Likewise, the Spearman's Rho correlation coefficient obtained (0.217) was low, but significant.

\section{Discussion}

The COVID-19 pandemic that humanity is going through, especially the health sector which is the first line of defense and therefore the nursing professional, supports the evidence that the frequency of mental health problems in health professionals at the front line of emergencies caused by viral epidemics is especially high, indicating a high prevalence of anxiety, depression, acute stress, burnout and post-traumatic stress, insomnia, among others (Serrano, et al.,2020; Tan, et al., 2020; Yuanyuan et al., 2020; Lai, et al.,2019).

As for the stress that negatively affects the psychological and physical health of workers and the occupational risk that can be increased and that represents a considerable part of the disease burden (Stavroula, et al.,2004; WHO, 2017). It should be noted that nursing professionals are a vulnerable group in the health sector in these aspects (Marcelo,2015). The results show that the relationship between occupational risk and occupational stress, determine a low but significant direct correlation, with a correlation coefficient of 0.364 . This finding is similar to that found by Dionisio, who also presents a low and significant direct correlation with a coefficient of 0.220 . From this, it is clear that there is an association between the occupational risk experienced by the nursing staff in this period and the stress generated by their work environment (Dionisio, 2017). 


\section{GHM \\ Journal of Global Health and Medicine}

Vol. 6, $\mathrm{N}^{\circ} 1,2022$

Copyright @ 2022, CINCADER.

ISSN 2523-9511

DOI: https://doi.org/10.32829/ghmj.v6i1.162

However, it is necessary to reduce much more drastically the occupational risks present, as well as to promote good practices to avoid occupational health problems that affect nurses during their professional work. It should be noted that stress is a phenomenon inherent to the work of care, which occurs in the face of difficulties and adversities, lack of material and human resources, among others, to address the patient in a comprehensive manner. A professional with a high workload and an environment plagued with risks is more susceptible to high levels of stress. The COVID-19 pandemic has multiplied the rates of mental health problems such as sleep disturbance, tiredness, anxiety, fatigue, etc., so it is necessary to implement coping strategies to reduce the impact on mental health.

Regarding the relationship between biological risk and occupational stress the results of the study showed a value $p<0.01$, therefore, both variables are not related. This finding differs from Dionisio (2017) who presents a low and significant direct correlation with a coefficient of 0.594 . It should be taken into account that biological risk is typical of critical areas, although current health policies try to neutralize such biological factors. This biological risk currently constitutes a latent danger for health personnel, especially for nurses who are in close contact with patients, which can lead to contagion causing illness and even death. This COVID-19 pandemic, although it is true that it triggered contagion among people, also allowed the strict use of different personal protective equipment to mitigate the degree of contagion between caregiver and patient and vice versa. It is worth mentioning that two simple measures such as hand washing and social distancing have managed to avoid high rates of morbidity and mortality due to COVID-19, which shows that minimizing biological risk does not always require costly measures. What remains for us to do from now on is to consolidate the use of these teams and maximize their benefits (Dionisio, 2017). In reference to the relationship between chemical risk and work stress, the results do not show an association between both variables. This finding is similar to that found by Dionisio, where there is no association between both variables. However, chemical risk is latent in critical and oncological services, which generates situations that may increase physical or mental health problems. Although it is true that the use of chemical substances (antiseptics, disinfectants and others) to prevent the spread of microorganisms is routine, the COVID-19 pandemic demonstrated that in the face of new microorganisms the protocols for the use of these substances are changing and adapting to new realities. Likewise, in an oncology center such as INEN, the use of cytostatics can increase occupational risk, but there is still little evidence of direct harm from these substances, which gives us light to new study alternatives in favor of the nursing professional in oncology establishments (Dionisio, 2017).

According to the results, there is no evidence of a relationship between physical risk and occupational stress. This finding contrasts with that obtained by Dionisio where there is an association between both variables. In spite of the fact that the sanitary facilities in our country are not the most adequate, the nursing personnel do not consider it as an obstacle, on the contrary, they manage to adapt to it and turn it into an opportunity for improvement (Dionisio, 2017).

Regarding the relationship between psychosocial risk and work stress, the results of the study showed a low but significant association between both variables $(p=0.007)$ with a correlation coefficient of 0.348 . This finding differs from that found by Dionisio (2017) in which there is no correlation between both variables. As noted above, the natural fear of contracting COVID-19 disease is altering the global mental health reality and is leading the world to rethink management strategies for these disorders. In the internal environment, despite the fact that the emergency nurse has skills in humanized patient care and assertive communication, possible hostile actions of both the patient and/or companion are perceived, recognizing that both the patient and his family in an emergency situation live situations of uncertainty, susceptibility, suffering, anger, etc., which can lead to emotional crises, aggressions, threats and alteration of the entire care process. In spite of this, the emergency nursing professional is able to develop communication skills, 


\section{GHM \\ Journal of Global Health and Medicine}

Vol. 6, $\mathrm{N}^{\circ} 1,2022$

empathy and becomes a mediator between the patient and the caregiver, therefore, a great responsibility falls on him/her to obtain the best results in the whole process. However, it is necessary to promote conflict prevention workshops rather than conflict management workshops (Dionisio, 2017).

Finally, no relationship was found between ergonomic risk and stress. This finding differs from that found by Dionisio (2017) in which there is a correlation between both variables. With respect to this section, the present study supports the thesis of the adaptation of the nursing professional to potentially adverse situations, also, currently the subject of ergonomics at work has become a constant in training, since the institutions recognize that a non-ergonomic environment causes absenteeism, loss of hours worked, temporary or permanent incapacity, work overload for the rest of the professionals, etc. In addition, the nursing professional recognizes that his care work is essential, therefore, he becomes an "expert" in adapting to his work environment. However, the continuity of training sessions on ergonomic issues is necessary.

Additionally, it was possible to determine the levels of occupational risk and occupational stress separately; in reference to this, it was obtained that $46.6 \%$ of the participants had a high occupational risk level, $43.1 \%$ had a medium risk level and $10.3 \%$ had a low occupational risk level. In contrast with these results, Dionisio determined a high occupational risk level of $80.9 \%$, medium level of $14.5 \%$ and low level of $4.5 \%$, while (Dionisio, 2017). Escobar and Vargas (2017) reported $16.7 \%$ corresponding to high occupational risk, 50\% medium risk and $33.3 \%$ low occupational risk. All this could suggest that those work environments did not have acceptable occupational safety measures or that, on the contrary, the INEN emergency service has better standards compared to other similar ones. Secondly, with respect to work stress, $46.6 \%$ presented high work stress, 32.8\% medium stress and 10.3\% low stress; while Dionisio (2017), shows that $36.4 \%$ presented a high level of stress and $54.5 \%$ a medium level; in turn, Peralta presents $46.6 \%$ corresponding to medium work stress, and $26.7 \%$ for the high level. From what has been described, it can be attributed that the significant differences between both results may be due to the period in which they were evaluated, since the study that was carried out involves the component of the COVID-19 pandemic (Peralta, 2019).

Finally, it can be affirmed that occupational risk is increasing in environments that are perceived as unsafe or that do not comply with personnel protection standards; in turn, an association was found with the occupational stress generated. Likewise, of the subtypes of occupational risk, only psychosocial risk was associated with occupational stress. On the other hand, occupational stress, which occurs daily in nursing personnel, is circumstantially increased by this pandemic.

\section{Conclusions}

In the present study it was evidenced that occupational risk was significantly related to occupational stress in nurses attending patients with COVID-19 in INEN Emergency. The psychosocial risk dimension was significantly related to occupational stress. While the dimensions of biological risk, chemical risk, physical risk and ergonomic risk were not related to occupational stress.

\section{References}

Dionisio V. 2017. Riesgo laboral y estrés laboral en profesional de enfermería del Instituto Nacional de Ciencias Neurológicas, Lima 2017. [Thesis for Master degree]. Lima: Escuela de Posgrado de la Universidad César Vallejo; 2018. https://hdl.handle.net/20.500.12692/12860

Escobar D., Vargas R. 2017. Riesgos laborales en profesionales de enfermería del hospital Zacarías Correa Valdivia de Huancavelica - 2017. [Thesis for professional Title]. 
Huancavelica: Universidad Nacional de Huancavelica; 2017. http://repositorio.unh.edu.pe/handle/UNH/1104

Hernández R, Fernández C, Baptista M. 2014. Metodología de la Investigación. 6ª ed. México: Mc Graw Hill; 2014.

Iniesta A. 2016. Guía sobre el manejo del estrés desde Medicina del Trabajo. Barcelona: Diputación

de

Barcelona. https://www.diba.cat/documents/467843/84449103/GuiaManejoEstres.pdf/eaaa8855d85c-40dc-8492-b998112989e0

Instituto Nacional de Seguridad y Salud en el Trabajo. 2012. Servicios de salud en el trabajo. En: INSST, editores. Enciclopedia de salud y seguridad en el trabajo en la OIT. Madrid: Tomo I. Cap. 22-23. https://www.insst.es/documents/94886/161958/Cap\%C3\%ADtulo+16.+Servicios+de+salu d+en+el+trabajo

Lai J, Ma S, Wang Y, Cai Z, Hu J, Wei N et al. 2020. Factors Associated With Mental Health Outcomes Among Health Care Workers Exposed to Coronavirus Disease 2019. JAMA Netw Open; 3(3). doi:10.1001/jamanetworkopen.2020.3976 https://es.jamanetwork.com/journals/jamanetworkopen/fullarticle/2763229

Marcelo E, Mayta J. 2015. Riesgos ocupacionales en el profesional de enfermería que labora en la unidad de cuidados intensivos de un hospital nacional de Lima. [Thesis for professional Title]. Lima: Universidad Peruana Cayetano Heredia; 2015. http://repositorio.upch.edu.pe/handle/upch/568

Peralta K. (2019). Nivel de estrés laboral del profesional de enfermería de emergencias del Hospital Marino Molina. Comas, 2019. [Thesis for professional Title]. Lima: Universidad César Vallejo. http://repositorio.ucv.edu.pe/bitstream/handle/20.500.12692/40790/Peralta_SKS.pdf?seq uence $=1$ \&isAllowed $=y$

Preciado M., Ambriz A, Enríquez C., Hernández G. (2016). Análisis psicométrico de la escala de estrés para profesionales mexicanos de enfermería. RICS. ; 5(10): 12. https://www.researchgate.net/publication/312929255

Serrano M., Meneses J., Ricci I, Fraile D, Fiol de Roque M., Pastor, G, et al. (2020) Impact of viral epidemic outbreaks on mental health of healthcare workers: a rapid systematic review and meta-analysis. J Affect Disord. 23; 277: 347-357. https://doi.org/10.1101/2020.04.02.20048892

Stavroula B., Griffiths A, Cox T. (2004). La organización del trabajo y el estrés. Nottingham: Instituto de trabajo, salud y organizaciones - Universidad de Nottingham; 2004 https://www.who.int/occupational_health/publications/pwh3sp.pdf?ua=1

Tan B, Chew N., Lee G., Jing M, Goh Y, Yeo LL. et al. (2020). Psychological Impact of the COVID-19 Pandemic on Health Care Workers in Singapore. Ann Intern Med. 173(4):317320 https://doi.org/10.7326/M20-1083

WHO, (2017) World Health Organization. Protección de la salud de los trabajadores. [Internet] Ginebra: [fecha de acceso 10 de junio del 2020] Disponible en: https://www.who.int/es/news-room/fact-sheets/detail/protecting-workers'-health

World Bank. Indicadores de desarrollo mundial. (2020) http://datatopics.worldbank.org/worlddevelopment-indicators/themes/people.html\#labor-force-structure

Yuanyuan Mo MM,Lan Deng MM,Liyan Zhang BM,Qiuyan Lang BM,Chunyan Liao BM,Nannan Wang BM,Mingqin Qin BM,Huiqiao Huang MM, 2020. Work stress among Chinese nurses to support Wuhan in fighting against COVID-19 epidemic. J Nurs Manag.; 28(5):1002-1009. https://doi.org/10.1111/jonm.13014

Zambrano G. (2006). Estresores en las unidades de cuidado intensivo. Aquichan; 6(1): 156-69. http://www.scielo.org.co/scielo.php?script=sci_arttext\&pid=S1657-

$59972006000100015 \& \operatorname{lng}=$ en 